\title{
Foundation seeks enhanced role in Europe
}

Strasbourg. The European Science Foundation (ESF) wants to change direction and establish itself as an influential European science policy forum capable of playing a key role in shaping European research. Next week's annual assembly of the foundation will vote on a package of changes designed to raise its profile and influence at both national and European levels.

The ESF was set up 19 years ago, and since then has been quietly but effectively running scientific networks, workshops and a limited science programme. For the past year, however, it has been engaged in defining a more important role for itself.

One thing will not change. The foundation, which at present has 54 member organizations from 20 different countries, will continue as a non-governmental, pan-European organization concerned with all fields of fundamental research.

But the opening up of eastern Europe and the increasing importance of the research programme run by the European Commission - much of which is now directed to fundamental research and overlaps

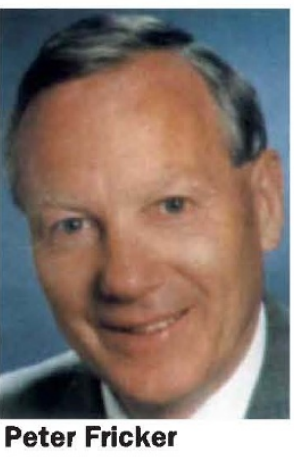
with ESF activities - have prompted a reassessment of its general aims.

Pressure for change in Europe has also come from national research organizations. In the past year, a group of heads of such organizations, known as the 'Eurohorcs', have been seeking more direct control over the research money spent by the European Community (EC). They would like the ESF to become a much stronger forum through which their voices could be heard in Brussels.

Peter Fricker, a founder member of ESF and former chief executive of the Swiss National Science Foundation, who took over as secretary general in April, is keen for the foundation to develop in this direction. $\mathrm{He}$ believes it would allow the foundation to act as a general champion of fundamental science, which he feels to be under threat in many European countries.

Next week's assembly of the ESF will debate proposals to place a financial limit on ESF science programmes, at least to their present level, while extending its strategic roles, and to develop stronger and more formal links with both the EC commission and the countries of central and eastem Europe.

ESF officials would also like the foundation to play a central role in defining future requirements for major scientific facilities in Europe, in assessing long-term prospects for scientific developments, and in monitor- ing the scientific output of, for example, major national and European laboratories.

The proposal to adopt a more strategic role is likely to be accepted by the meeting. But some controversy may also arise. For example, the ESF will have to ensure that it does not duplicate the activities of other organizations, such as the Organization for Economic Cooperation and Development.

Fricker also recognizes that the foundation cannot force the EC to accept its proposals. While the commission is likely to react favourably to a system which offers structured advice from the basic science community, it cannot legally delegate any decision-making to an outside body.

Fricker says he is aware that issues such as the delegation of activities such as grant refereeing - an idea that the ESF has considered in the past - could raise legal difficulties. Similar direct approaches to the commission by the Eurohorcs have not been wholly welcomed, since they are seen as a threat to the authority of the commission.

More acceptable to the commission is likely to be an extension of ad hoc cooperation with the ESF. There have already been some successful examples of this, such as

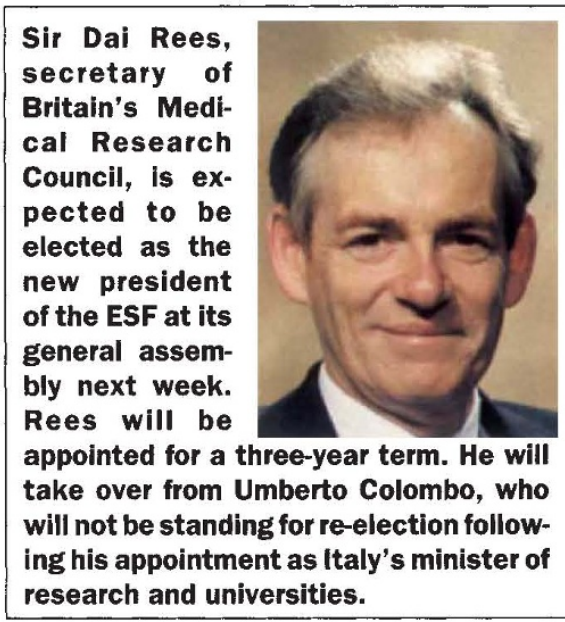

the European Research Conferences, which are modelled on the US Gordon Conferences and are funded by the EC and organized by the ESF.

Fricker says that the ESF is likely to rely much more in future on member organizations, for example to manage specific scientific activities. How the changes within the ESF might be paid for is at present being left open until its future plans become more concrete.

Alison Abbott

\section{Kohl limits money for universities}

Munich. Helmut Kohl, the German chancellor, promised at a long-awaited education summit in Bonn last week that he would set up a committee to look at ways in which the country's federal higher education law might be changed to give universities more freedom to set entrance examinations and control their own budgets.

The summit was originally called by Kohl in spring of last year in response to charges that the universities face too many students staying for too long.

But Kohl made no commitment to increase funds for building and maintenance of higher education institutions, and announced only a small increase in funds for research in the new Länder. Many regional representatives, who want the federal government to pledge more cash to help reforms, were disappointment by his speech

The prime ministers of Germany's 16 Länder, which have full responsibility for running institutes of higher education in their regions but depend on federal funds for building, maintenance and large equipment, had asked the government to increase the 1994 building budget from DM1.68 billion (US\$950 million) to DM2 billion.

This in itself was a compromise. The Wissenschaftsrat - Germany's science advisory council - has calculated that at least DM2.3 billion is required to maintain exist- ing buildings at universities and other higher education institutes, even without any expansion. But Kohl refused any increase.

In sticking to its guns, the federal government runs the risk that the prime ministers, who control the Bundesrat, Germany's upper house, will delay the passing of the whole federal 1994 budget later this year by taking the unusual step of referring the issue to the Vermittlungsausschuss, a mediation committee with the Bundestag.

The Wissenschaftsrat had also recommended an increase in federal spending of DM300 million on research. But, in light of the government's attempts to keep a tight lid on public spending, Kohl has agreed to only half of this increase, and has also earmarked the extra money for industrial research in the new Länder.

Gerhard Neuweiler, head of the Wissenschaftsrat, says that the government appears to have no interest in investing in universities. He suggests this was the main reason for the summit being delayed for more than a year, and finally taking the form of a series of position statements which were not open to discussion.

Some see Kohl's promise to set up a committee to look at future reforms as a delaying tactic. But others are more optimistic, and believe that the law could still be reformed next year.

Alison Abbott 